\title{
PRISON BY HUMAN RIGHTS' LENS AND COVID19 PANDEMIC - THE BRAZILIAN CRISIS
}

\author{
Cláudio Brandão ${ }^{1}$ \\ Renato Feitosa ${ }^{2}$
}

\section{Abstract}

From the eighteenth century, prison was raised as the main response of Criminal law. This happened for a political reason, namely the creation of State. In this context, incorporations that the ideologies and characteristics of later centuries brought to prison entail an aporia. To face this crisis, Human rights has produced criteria that should guide the actions of States. The COVID19 pandemic caused urgency of segment of these criteria and the Brazilian case is brought up as an example of failures of most UN member States.

\section{Keywords}

Crisis of Prison. Penitentiary architecture. Mandela Rules. COVID19 and prison. Brazilian's prison crisis.

\section{Summary}

1. Introduction: prison as primary criminal response. 2. State and prison: $18^{\text {th }}$ Century ideology. 3. Penitentiary architecture: $19^{\text {th }}$ Century legacy. 4 . The technological society: $20^{\text {th }}$ Century changes. 5. The centuries of imprisonment crisis. 6. Human rights' answer to prison crisis and the Brazilian case. 7. The Brazilian crisis and COVID19 pandemic. 8. Final note.

${ }^{1}$ Full Professor. Pontifical Catholic University of Minas Gerais, Damas Cahotlic College and Federal University of Pernambuco.

${ }^{2}$ Lecturer at Damas Catholic College. 


\section{INTRODUCTION: PRISON AS PRIMARY CRIMINAL RESPONSE}

Prison is the backbone of contemporary penalty system ${ }^{3}$. This is because in all western countries ${ }^{4}$ the primary response to criminality is done through it; the rest of the penalties are only devised either to replace the prison or to be applied cumulatively to it. However, since of the twentieth century, the penalty of deprivation of liberty (rectius, prison) has been subjected to acute criticism which has raised the issue of the prison crisis in criminal science. Zaffaroni, for example, claims that the prison is substantially a storehouse for deteriorated human beings ${ }^{5}$. This crisis was motivated by the European model of a social and democratic welfare State which is incompatible with a type of sanction carried out in an establishment that eliminates human beings and their dignity ${ }^{6}$.

Even with the criticisms, the prison sentence still remains the primary response to criminality, since another type of response has not been able to remove its prominence. Outside of science, these criticisms are generally met with irrationality ${ }^{7}$. However, its crisis remains, because, to paraphrase Zaffaroni, the observation of the facts shows that the prison units are not just a place of confinement, removing the ability of movement. In fact, these

3 'The prison sentence remains the backbone of the penal system, because it is the only reaction that can be suitable for serious crime and for average crime not covered by the fine, as well as for frequent recidivism". JESCHECK 1988, 678.

${ }^{4}$ Prison is an institution common to western States, although, as Langer warns, there are significant differences in penal systems, because after the fall of the Roman empire in the fifth century, different practices were generated to replace Roman customs. LANGER 2017, 47. There is a consensus in the West to associate prison with the criminal response to guilt, rejecting liability without guilt. See FLORÊNCIO FILHO 2016, 191.

${ }_{5}^{5}$ ZAFFARONI 2002, 932-933.

${ }^{6}$ JESCHECK 1988, 674.

7 "Therefore, insofar as criminal tutelage is popularly invoked as an instrument aimed to restore an emotional balance shaken by the fear of violent criminality, every popular demonstration within the political-criminal debate would invariably be endowed with a strong irrationality component " GLOECKNER et al 2017, 264 
units became the place to eliminate the person who committed a crime, since these prisons were transformed into physical or psychic extermination camps (or both), with greater or lesser sophistication, according to the country's economic potential ${ }^{8}$.

The penalty of deprivation of liberty affects, as said, freedom of locomotion, removing from subjects the right to dominate movements, according to their will. This means, as stated above, that deprivation of liberty directly affects time of the person serving it. In fact, Aristotle already linked the movement to the notion of time; for him, time is the number of movement, according to before and after ${ }^{9}$. Therefore, by removing freedom of locomotion, which is essentially freedom of movement, the prisoner's time is reached. The withdrawal of time is a way of deconstructing the human being. When taking time out, part of social existence is subtracted, that is, subtracted from the convict's own life, which annihilate the dignity of the human being.

\section{STATE AND PRISON: $18^{\text {th }}$ CENTURY IDEOLOGY}

Prison, as an autonomous institution in Criminal law science, which confines someone in an establishment, depriving them of selfdetermination of movement and locomotion, is the product of the political position defended in eighteenth century, which thereby diverted the focus of corporal punishment from Criminal law ${ }^{10}$. However, physical infrastructure of prison as an autonomous sentence, which gave material support to the confinement, depriving freedom of movement in a complete way, was only implemented in the subsequent century, that is, in the nineteenth century with the development of penitentiary systems. According to Cuesta Arzamendi:

\footnotetext{
8 ZAFFARONI 2002, 933.

9 ARISTÓTELES, Física, IV, 219a-219b

${ }^{10}$ MANTOVANI 1988, 729.
} 
"(...)medieval monastic orders imposed the deprivation of liberty for punitive purposes. However, it was only from the Modern Age onwards, with the rebirth of forced labour and the development of correction institutions, that the use of prison was consolidated, which later in the $18^{\text {th }}$ century will find a prominent place in the liberal systems list of penalties, becoming widespread during the $19^{\text {th }}$ Century through penitentiary systems." 11

The humanitarian ideas of the $18^{\text {th }}$ Century included in the existing debate of punishment's scope questions related to the abandonment of corporal punishment. The issues related to prevention and retribution are much older than the end of modern period, being enough, to prove this fact, the ancient latin denominations that characterize them, namely punitur quia pecatur, for retribution, and punitur ne peccetur, for prevention. These terms were created by Seneca inspired by Plato. In fact, Plato already in Greek antiquity, saw the essence of this dichotomy when affirming that:

"(...) this is so certain, Socrates, that if you want to take the trouble to examine what this expression means: punish the wicked, the force that has the end that we propose with this punishment. (...) Why does no one punish a bad man just because he has been bad, unless it is a ferocious beast that punishes to satisfy his cruelty. (...) But what he punishes with reason, punishes, not because of past faults, because it is no longer possible for what

${ }^{11}$ ARZAMEDI 1983,. 139. 
has already happened to cease to happen, but for faults that may arise, so that the culprit does not recur and serves as an example to others as a punishment $" 12$.

The $18^{\text {th }}$ Century authors wanted to demonstrate that corporal punishment, applied by those in power (nobles and clergy), were not linked to the humanizing purposes that would make the legitimation of Power. So, eighteenth-century's philosophy proposed a discourse that moved away from those corporal punishments. This speech linked the prevailing power, which they called - in a derogatory way - "the ancient regime", to the penalties that imposed as punishments on the bodies of the condemned, and started to defend a substitute institution: prison. The latter would be monopolized by the new form of political organization proposed, namely the State.

Prison, therefore, would ultimately be the instrument that would enable State criminal control and break the powers of the clergy and the nobility to impose criminal sanctions, which tooked place through corporal punishment. For that, the humanization discourse was a convincing mechanism, since the abuses of both, clergy and nobility, provoked a trajectory of terror that cost human history more pain and suffering than the war itself. However, criminal humanization through prison was nothing more than a speech. Deprivation of liberty as a penalty is nothing more than the extermination of human being by the deprivation of their time, which makes it conceptually incompatible with the promotion of human dignity, that is, with humanization ideas.

3. PENITENTIARY ARCHITECTURE: $19^{\text {th }}$ CENTURY LEGACY

12 PLATÃO 1993, 115. 
The space for infliction of criminal punishment is present in the history of mankind long before the affirmation of prison. Such locus was the anteroom for corporal punishment, so there is no spatial methodology in it as it exists in the penalty of deprivation of liberty. So, physical space of infliction of punishment on the convict's body, more often taking his life, does not have the need for a specific architecture, such as prison requires.

The idea of deprivation of liberty as a sentence led, at the end of eighteenth century, to a movement in the United States of America to carrying out penitentiary reform, both in Philadelphia (1790) and Auburn (1821). This movement, combined with the panoptic prison surveillance system, proposed by Bentham (1791), formed the engines for the construction of a prison infrastructure with an architectural method, which provided the physical support for the development of institutions specialized in the suppression of freedom of movement and defendants' time, through potential continuous surveillance.

The nineteenth century made prison the protagonist institution of the State system. Through surveillance and the imposition of discipline, a segregation architecture was made to deprive ordinary human interactions. This caused an architecture of power over the body of convicted ${ }^{13}$, which deprived the subject not only of the ability to move, but of human contact, taking away time and life, as it is ordinarily known.

13 About the contemporary approach of this theme, see Agata Amato Mangiameli: "It is more difficult to speak about the relationship between punishment and body, especially punishment and de-formed body, when the human body, is so to speak, abandoned (...). must however reflect the proprium of the penal sanction: this is essentially the repression of will, and only indirectly is it a repression of sensitivity. Or better still, the penalty cannot be just any kind of suffering: it must be a distress that purposely denies and humiliates the wicked will embodied in the deeds”. AMATO MANGIAMELI 2016, 141-142. 
Prison is the antithesis of the active ordinary life. It "with greater clarity, imposes individual discipline and mass control, as was proposed in the Panopticon"14.

The formation of the word panoptic translates its architectural meaning: see (optical) everything (pan). This physical infrastructure made it possible for the prisoner to be observed without being able to see the guards. In this way, the power of observation reached the person subjected to the penal system through two characteristics: (i) subtraction of human interactions and (ii) susceptibility of permanent observation.

\section{THE TECHNOLOGICAL SOCIETY: $20^{\text {th }}$ CENTURY CHANGES.}

Twentieth century brought to prison uniques challenges. The deprivation of liberty was deeply affected by rapid and profound changes in social characteristics due technology, which took place from the nineties of twentieth century until present. These changes reconfigure the boundaries of space-time, removing old limits to social interactions and bringing new characteristics, on the one hand, and new risks, on the other side. Technological innovations are developed in shorter and shorter periods of time for a society that has moulded itself to a technological adoption as fast as its own production.

The internet was created by United States Department of Defence in 1969, as a result of a project called ARPANET, with the function of integrating various research laboratories and ensuring that communication between military and scientists would remain, even in military attacks ${ }^{15}$. But the

${ }^{14}$ ANITUA 2008, 219.

15 On the theme: "In addition to being a response to technological disputes between the US state and the extinct Soviet Union, ARPANET was designed to be an independent military communication network, with a single server, that is, without a command with the aim of preserving the system's operability through nuclear attacks. Subsequently, its use was made available to universities, being gradually disseminated in academic circles " CAZELATTO et al 2014, 390. 
impact that internet had on social interactions was the result of creation, in the early nineties of twentieth century of a worldwide network (1992), the world wide web (www), which made possible to connect computers all over the world, followed by the creation of the first browsers (Mosaic and Netscape). In this context, internet has become the platform on which modern society has built its legacy, by suppression old space and time limits. Consequently, human relations have never been more explored than they are in the virtual world, at the same time that new concepts worthy of study are emerging that shape the way in which modern man interacts with people and the world around them ${ }^{16}$.

In this context, the isolation ideally created for the deprivation of liberty finds a contradiction due to the recompositing of human relations. A cell phone connected to the internet, for example, makes the segregation projected by prison impossible and further interactions becomes possible through technology, nullifying the whole project linked to this type of sanction. Thus, this aspect of prison's crisis is brought up from the twentieth century.

\section{THE CENTURIES OF IMPRISONMENT CRISIS}

Prison, as a total institution that suppresses freedom of movement in space and produce elimination of time, went into crisis due the convergence of antagonistic characteristics of three successive centuries. In fact, it should first be noted that, from the eighteenth century onwards, the ideal of deprivation of liberty - including the appropriation of the previous discourse

${ }^{16}$ It should be noted that, on the internet, "at the same time as this great repository of information and knowledge expands, fearful looks see the development of an 'other' internet, where virtual crimes are common, professionalized, difficult to reach, besides being connected, at times, to the political, economic and ideological interests of the transnational companies " SILVA 2018, 261. 
about purposes of punishment - began with the liberal revolutions. In second, nineteenth-century prison systems have developed the physical infrastructure of prisons, guided by surveillance control. Moreover, technological development that emerged from the twentieth century has made it possible to eliminate physical barriers to social interactions. In twentieth century - and also in present - physical isolation no longer means an absence of human relationships, since internet and the technological resources have removed much of the physical barriers for interactions. Consequently, the penalty of deprivation of liberty was conceived through the mentality of liberal thought in the eighteenth century, developed materially through the penitentiary institutions and their systems in the nineteenth century and faced the characteristic of suppressing limits for social interactions in the twentieth century. The convergence of the antagonism of these three centuries brought an aporia in the $21^{\text {st }}$ Century. It should be noted that this aporia was already foreseen in the twentieth century, in German Criminal law science, which defined prison as a bitter need within the community formed by imperfect human beings ${ }^{17}$. However, prison continues to mean the monopoly of the State's power to punishment. There is, therefore, a political component that places it as a necessity for the existence of the structural organization of societies, from the liberal revolutions of the eighteenth century to present. The challenge facing legal scientists, in this scenario, is to limit the harmful effects of this crisis. The path to this scope is to apply to prison the limitations arising from international normative Human rights system ${ }^{18}$.

\section{HUMAN RIGHTS' ANSWER TO PRISON CRISIS AND THE BRAZILIAN CASE}

17 BAUMANN 1969, 29.

${ }^{18}$ For Human rights' function of limitation of State power, see BRANDÃO 2020, 5 et seq.; BRANDÃO 2019, passim. 
International community, recognizing the bankruptcy of prison as the primary criminal response and its incompatibility with the values originated by Human rights, brought to the discussion the need to establish minimum conditions for imprisoned people.

Certain of the inexorability of this system applied globally as a way of controlling crime and recognizing the problems arising from mass incarceration and absence of effective policy of reintegration, as well as recognizing the need to observe the principle of Human dignity to prisoners, the United Nations standardized the "United Nations Minimum Rules for the Treatment of Prisoners", approved 1955 and in force through Resolutions 663c, of July 31 ${ }^{\text {st }}, 1957$ and 2076, from May 13 ${ }^{\text {th }}, 1977$. These rules were revised in Vienna, Buenos Aires and Cabo and this document was named Mandela Rules, in honour of the leader, awarded the Nobel Peace Prize, Nelson Mandela. So, Mandela Rules were established as guidelines for States to face the increasingly prison's serious problems in contemporary world.

Despite the recognition of Mandela Rules by Brazil, Brazilian prisons suffered a series of regressions regarding the preservation of the principle of Human dignity under several aspects of prison system, namely: (i.) Precarious and insufficient infrastructure for the demand of prisoners; (ii.) Lack of personnel (i.e., security professionals; maintenance; health; education); (iii.) Poor quality of the prison facilities; (iv.) The neglect in observe the legality principle itself, by failing to keep its integrity in the Criminal Execution act and in the Brazilian Constitution; (v.) The absence of the State in assisting the condemned and egressed from the prison system to reintegration; (vi). pari passu, the upsurge of policies for the criminalization of poverty and the application of selective criminal law ${ }^{19}$,

19 Brazilian's doctrine recognizes that a non selective Criminal law system is far from present reality. See, for exemple, FREITAS 2020, 146. 
with the corollary of a mass incarceration even more evident within an already unstable reality of prison's overpopulations.

In fact, Brazilian prison system has always been far from meeting the minimum guidelines set by Mandela Rules, bringing serious violations of Human rights, triggering the creation of "parallel states", massacres and rebellions with agendas regarding the poor quality of the prison system or speed in the analysis of the processes involving the penalties' progression of the convicted, extinction of the sentence or granting of parole ${ }^{20}$. Mandela's rules are norms with the purpose not only of preserving individual's rights but also, in view of the essential objectives of the criminal justice policy, to ensure that the convict has, through the dynamics of serving his sentence, means of save their Human dignity.

\section{THE BRAZILIAN CRISIS AND COVID 19 PANDEMIC}

Brazilian prisons produce the extermination of Human being. The Constitutional Court has named the situation as an incomprehensible "unconstitutional remained of matters", because the court recognizes the State violations both the Brazilian Constitution and Mandela Rules, but at the same time don't command concrete actions regarding to change the State violations of $\mathrm{Law}^{21}$. Brazilian Constitution and Mandela Rules

20 (v.g.: Massacre do Carandiru: 1992, 111 killed by the police, with no criminal responsibility; Anísio Jobim Penitentiary Complex: 2017, with 56 deaths from a faction war; Monte Cristo Agricultural Penitentiary: 2017 with 33 dead, some with beheadings and eyes or hearts ripped out; Benfica: 2004, 30 dead; Alcaçuz: 2016, 26 dead; Prison Doctor José Mario Alves da Silva (Urso Branco): 2002, 27 dead; Pedrinhas , 2010, 18 dead; Altamira, 2019, at least 52 dead, with 16 beheadings).

${ }^{21}$ STF. ADPF347 MC/DF, rel. Min.Marco Aurélio. See, also: "The Brazilian State continues to reach one million prisoners, in a calamitous context that is the product of public policies that continue to neglect human rights and, even worse, allowing 
command that no one shall be subjected to torture or inhuman or degrading treatment. Although it is a fundamental right of unfailing observance, when analysing the Brazilian prison reality, we note the wide gap between what should be and reality.

Also, Rule $6^{22}$ of Mandela's Rules order that there should be a standardized system for registering prisoners in all places of incarceration. The Brazilian Constitution establishes in its art. 24, item I, that the competence to deal with penitentiary law is competing between the State, Provinces and Municipalities, with the normative production being created according to the competence and reality that presents itself in the regional context. In this sense, the State has the competence to establish general rules within the scope of penitentiary law, and it is up to the States to act in a supplementary manner or fully, in the absence of the Union, depending on the peculiarities that appear in the region ${ }^{23}$.

It is observed that the conduction of normative production must take place in a coordinated and systematic way and it is up to that State-part of smaller circumscription to establish special rules according to the reality presented (number of prisoners, quality of prisoners, demand for places of detention or special treatment - id est lactating, sick, et cetera). That said, analysing the balance sheet of the penitentiary system carried out at the end of 2019 and

institutionalization in the prisons of violence (physical, psychological and moral)", PEREIRA 2020, 200

${ }^{22}$ Rule 6 There shall be a standardized prisoner file management system in every place where persons are imprisoned. Such a system may be an electronic database of records or a registration book with numbered and signed pages. Procedures shall be in place to ensure a secure audit trail and to prevent unauthorized access to or modification of any information contained in the system.

${ }^{23}$ Art. 24. It is incumbent upon the Union, the States and the Federal District to legislate concurrently on:

I - tax, financial, penitentiary, economic and urban law; $\ 2$ The competence of the Union to legislate on general rules does not exclude the supplementary competence of States. $₫ 3$ In the absence of a federal law on general rules, States will exercise full legislative competence to meet their peculiarities. 
the balance sheet carried out to control and take action to combat Covid19, there is a grey area in the correction of the data presented. Both in the 2019 ballot and in the Covid19 balance, the total number of prisoners is the same: 748,009 (seven hundred and forty-eight thousand and nine prisoners), revealing an implicit inconsistency in balance sheets with a time span of 7 months.

Thus, there is State's failure to establish an ostensible policy of control and monitoring of Covid19 within the penitentiaries. In fact, after verifying the community transmission of the virus, the Ministry of Health began to carry out tests only on patients with severe symptoms indicative of Covid19.

From this observation, the lack of care of public authorities in transparency with the information about the number of prisoners and the number of infected and killed by Covid19 can be seen, reflecting in precarious public policies (e.g. provision of protective and hygiene materials) supported by lagged values. A clear violation of articles 6 and 8 of the Mandela's Rules, revealing the difficulties that the scientific community faces with the imprecision of the information (or lack of it) published by the Public Administration.

Brazilian prison system, which today has more than 748,009 prisoners $^{24}$ (of which 222,558 are untried prisoners), has a maximum capacity (maximum contingent to affordable) of 442,349 prisoners allocated in 1,435 prison establishments throughout Brazil. If the number of spaces in the prison system focused on the health care of prisoners within the prison system is analysed, the issue becomes even more serious ${ }^{25}$ :

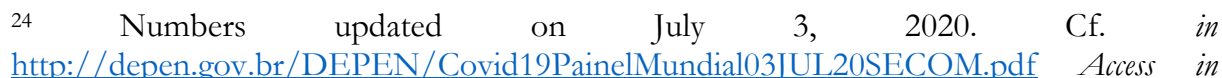
07.20 .2020 .

25 Data referring to the report of the second semester of 2019 in http://depen.gov.br/DEPEN/depen/sisdepen/infopen/relatorios-analiticos/br/br Access in 07.20.2020. 


\section{Brandão IPRISION BY HUMAN RIGTS' LENS AND COVID 19 PANDEMICI ISSN 2675-1038}

1. $38 \%$ of prisons do not have a doctor's office, at least;

2. $66 \%$ of the establishments do not have a physical structure that allows collection of material for the laboratory;

3. $67 \%$ of the establishments do not have observation cells;

4. $67 \%$ of the establishments do not have a toilet for patients;

5. $\quad 77 \%$ of the establishments do not have a sterilized material / purge center;

6. $79 \%$ of establishments do not have a sterilization room;

7. $88 \%$ of the establishments do not have a washing and decontamination room;

8. $96 \%$ of establishments do not have a diagnostic laboratory.

In this universe of 748,009 incarcerated, the prison system has 1,395 nurses (536.2 incarcerated per nurse), 2,473 nursing technicians / assistants (302.4 incarcerated per nursing technician / assistant), 1,151 doctors, including general practitioners and various specialties (649.8 incarcerated per doctor $)^{26}$, a number that falls below the minimum necessary to guarantee the health of prisoners in the current reality.

\section{FINAL NOTE}

26 Data referring to the report of the second semester of 2019 in http://depen.gov.br/DEPEN/depen/sisdepen/infopen/relatorios-analiticos/br/br Access in 07.20.2020. 
In this context, the threats arising from already precarious reality of prisoners in Brazilian prison system became even more pressing, presenting the violations of Rules 24, 25 and 27 of Mandela's Rules, as well as the constitutional values governing activities of Brazilian State.

The absence of policies to control the spread of disease coupled with the lack of cohesion between entities of the Public Administration reveal an emergency situation. Furthermore, there remains evidence of the negligence of the health authority responsible for supervising prisons.

\section{REFERENCES}

AMATO MANGIAMELI, A., "Surveillance or punishment? From docile bodies to programmed bodies". Delictae Revista de Estudos Interdisciplinares sobre o delito, 1, 2016. DOI: https://doi.org/10.24861/2526-5180.v1i1.6

ANITUA, G., História dos pensamentos criminológicos, Rio de Janeiro, 2008. ARISTÓTELES, Física, IV, 219a-219b.

ARZAMEDI, J. de la Cuesta, "La Prisión: Historia, Crisis, Perspectivas de Futuro", in A. Beristein (ed.) Reformas Penales de Hoy, Madrid, 1983.

BAUMANN, J et al., Alternativ-Entwurf eines Strafgesetzbuches. Allgemeiner Teil, Tübingen, 1969.

BRANDÃO, C., "Direitos humanos e corrupção: a interface entre poder e desenvolvimento na Convenção Interamericana contra a Corrupção", Ciências Criminais em Perperspectiva, 1, 2020, DOI: http://dx.doi.org/10.22293/ccrim.v1i1.1361 
BRANDÃO, C., "The roots of human rights: the epistemological turn provoked by Francisco de Vitória”, Humanities and Rights Global Network Journal, 1, 2019, DOI: https://doi.org/10.24861/2675-1038.v1i1.9

CAZELATTO, C. et al, "Dos crimes informáticos sob a ótica do ambiente digital constitucionalizado e da segurança da informação", Revista Jurídica Cesumar, 14 (2), 2014.

FLORÊNCIO FILHO, M, "Inexigibilidade de conduta diversa: uma análise politico-dogmática para momentos de crise financeira", Delictae Revista de estudos interdisciplinares sobre o delito, 1, 2016, DOI: https://doi.org/10.24861/2526-5180.v1i1.8.

FREITAS, R., "Teoria da adequação social: a dogmática do direito penal e a formulação dos critérios da conduta socialmente adequada", Ciências $\begin{array}{llll}\text { Criminais em } & \text { Perspectiva, } & & \end{array}$ DOI: $\underline{\text { http://dx.doi.org/10.22293/ccrim.v1i1.1365 }}$

GLOECKNER, R. et al, "Os sentidos do populismo penal: uma análise para além da condenação ética", Delictae Revista de estudos interdisciplinares sobre o delito, 2, 2017, DOI: https://doi.org/10.24861/2526-5180.v2i3.39.

HASSEMER, W., Fundamentos del Derecho Penal, Barcelona, 1984.

JESCHECK, H.-H., Lehrbuch des Strafrechts, Berlim, 1988.

LANGER, M., "Dos transplantes jurídicos às traduções jurídicas: a globalização do plea bargaining e a tese da americanização do processo penal", Delictae Revista de estudos interdisciplinares sobre o delito, 2, 2017 , DOI: https://doi.org/10.24861/2526-5180.v2i3.41.

MANTOVANI, F., Diritto Penale, Padova, 1988. 
PEREIRA, C. J. L. el al, "Pandemia de (in)dignidade: o coronavírus e o estado de coisas inconstitucional do sistema carcerário brasileiro", Ciências Criminais em Perspectiva, 1, 2020, DOI: http://dx.doi.org/10.22293/ccrim.v1i1.1367

PLATÃO, Diálogos, Mexico, 1993

SILVA, R., "Delito virtual: um diálogo sobre as transgressões online do mundo real", Delictae Revista de Estudos Interdisciplinares sobre o Delito, 3, 2018, DOI: https://doi.org/10.24861/2526-5180.v3i4.68.

ZAFFARONI, E. et alli, Derecho Penal. Parte general, Buenos Aires, 2002. 